\title{
Incidence, diagnosis and treatment of sinusitis in children and adolescents after hematopoietic stem cell transplantation
}

\author{
Ekaterina S. Utimisheva ${ }^{1}$, Oleg I. Dolgov ${ }^{1}$, Olesya V. Paina ${ }^{1}$, Kirill A. Ekushov ${ }^{1}$, Alina A. Vitrischak ${ }^{1}$, Boris I. Smirnov ${ }^{2}$, \\ Ludmila S. Zubarovskaya ${ }^{1}$, Sergey A. Karpischenko ${ }^{1}$, Boris V. Afanasyev ${ }^{1}$ \\ ${ }^{1}$ Pavlov First St. Petersburg State Medical University, St. Petersburg, Russia \\ ${ }^{2}$ St. Petersburg State Electrotechnical University LETI, St. Petersburg, Russia
}

Dr. Ekaterina S. Utimisheva, Clinical Otolaryngologist,

First St. Petersburg State I. Pavlov Medical University,

L.Tolstoy St., 6-8, 197022, St. Petersburg, Russia
Phone: +7 (921) 3136470

E-mail: otorino@mail.ru

Citation: Utimisheva ES, Dolgov OI, Paina OV et al. Incidence, diagnosis and treatment of sinusitis in children and adolescents after hematopoietic stem cell transplantation. Cell Ther Transplant 2019; 8(1): 46-53.

\section{Summary}

Sinusitis after allogeneic transplantation of hematopoietic stem cells occurs in $22.2 \%$ of cases being more frequent at $>100$ days following allo-HSCT, than at earlier terms $(\mathrm{p}=0.006)$. The main risk factors for sinusitis after allogeneic stem cell transplantation were as follows: sinusitis before allo-HSCT ( $\mathrm{p}<0.001)$, neutropenia duration for more than 10 days $(\mathrm{p}=0.054)$, acute $(\mathrm{p}=0.022)$ or chronic graft-versus-host disease $(p<0.001)$ in the patients. The main pathogens of sinusitis revealed in allo-HSCT recipients during the study were: Gram-positive Staphylococcus epidermidis (30\%), Streptococcus viridans (30\%); Gram-negative Klebsiella pneumoniae (17.5\%). A monoculture of bacteria predominated within 100 days posttransplant $(\mathrm{p}=0.011)$. Poly-etiological origin of the causative bacterial agents in sinusitis was more likely in adolescent patients, in comparison to the younger children group. The severity of changes in paranasal sinuses, as registered with computed tomography after 100 days after allo-HSCT, was more pronounced $(\mathrm{p}=0.014)$ than at earlier terms, thus being discordant with less common clinical signs of sinusitis $(p=0.008)$, and milder clinical course of sinusitis assessed by a visual analogue scale $(\mathrm{p}=0.032)$ during this period. Punctures of maxillary sinuses combined with antimicrobial therapy proved to shorten the duration of sinusitis treatment in these patients $(\mathrm{p}=0.024)$

\section{Keywords}

Sinusitis, children, hematopoietic stem cell transplantation.

\section{Introduction}

One of the urgent problems of modern otorhinolaryngology and clinical medicine are inflammatory lesions of the paranasal sinuses (PS). Over the past decade, the incidence of sinusitis has increased 3 times [1]. According to different authors, acute or chronic sinusitis suffer from 5 to $15 \%$ of the adult population and about $5-13 \%$ of children $[2,3]$. In the structure of stationary pathology acute sinusitis is $15-36 \%$ [4]. Every year, the number of hospitalizations for this reason increases by $1.5-2 \%$ [1].
Infections are a relevant problem for hematopoietic stem cell transplantation (HSCT) and cause of failure in the treatment of patients after transplantation. At the same time, there has been an increase in the number of immunocompromised patients, due to increased usage of HSCT for various oncological, hematological and hereditary diseases [5]. As a result, the risk of bacterial, viral, fungal infections increases at various sites, including the defeat clinically significant lesions of paranasal sinuses (PS) in such patients [6-14]. According to the published studies, the incidence of sinusitis among adult patients subjected to HSCT ranges from $21 \%$ to $36 \%$ [11, 15, 16]. Appropriate data on children and adolescents are absent in available literature. 
Currently we know about several retrospective studies of the factors associated with allo-HSCT procedure which increase the risk of PS affection in adults. Such studies are lacking in children and adolescents undergoing HSCT.

The patients with post-transplant leukocytopenia do not exhibit a typical inflammatory response, unlike immunocompetent patients. In this regard, the symptoms of PS lesions may be absent, or mildly expressed [11], thus making it difficult to diagnose these conditions. In addition, invasive procedures in HSCT recipients, e.g., diagnostic and therapeutic punctures of maxillary sinuses or mucosal biopsy in invasive PS mycosis, or PS lesion, as a manifestation of the underlying disease, may be associated with development of severe complications that aggravate general condition of the patient [17]. Meanwhile, X-ray diagnostics of PS at the specialized radiological units for detection of sinusitis at early terms after allo-HSCT is difficult due to limited access for the patients over the aplastic period since they have to be isolated in the wards equipped with laminar air flow and HEPA filtration.

Evolving sinusitis may be a factor contributing to development of other infectious complications (bronchitis, pneumonia) at the early and late terms after allo-HSCT [18].

Thus, the study of risk factors, diagnostic issues and therapy of inflammatory PS lesions in children and adolescents is a necessary condition preventing infectious complications after HSCT and, ultimately, providing a clinical success.
The aim of our study was to improve diagnosis and treatment of sinusitis in children and adolescents after allogeneic transplantation of hematopoietic stem cells. We have identified a subgroup of patients with increased risk for infectious complications after allo-HSCT, in particular, sinusitis, thus allowing to develop methods of its prevention and diagnosis, as well as early therapy of this condition.

\section{Patients and Methods}

The work was performed on the basis of retrospective and prospective analysis of medical records on the patients 0 to 21 years of age after autologous or allogeneic hematopoietic stem cell transplantation (HSCT), performed in R. Gorbacheva Memorial Research Institute of Children Oncology, Hematology and Transplantation at the First St. Petersburg State I. Pavlov Medical University over the period of 2008 to 2013.

The main group of the study consisted of 352 recipients $(67 \%$ of total) subjected to allo-HSCT at the age ranging from 4 months to 21 years (median, 12 years; gender ratio: 213 males and 139 females). The comparison group consisted of 172 recipients $(33 \%)$ who underwent autologous HSCT (autoHSCT), 1 to 21 years old (median of 12 years, the group included 101 males and 71 females). The spectrum of underlying disorders in HSCT recipients is presented in Table 1.

Remission of the underlying disease was observed in 195 patients with allo-HSCT, relapse, in 157 patients. At the auto-HSCT, 147 patients were in complete remission;

Table 1. Clinical characteristics of primary disease in the patients subjected to allo- or auto-HSCT

\begin{tabular}{|c|c|c|}
\hline Variables & $\begin{array}{l}\text { ALL0-HSCT } \\
(n=352)\end{array}$ & $\begin{array}{l}\text { AUT0-HSCT } \\
(\mathrm{n}=172)\end{array}$ \\
\hline Gender, boys/girls & 213/139 & 101/71 \\
\hline \multicolumn{3}{|c|}{ Diagnosis (\%) } \\
\hline Acute leukaemia: & $259(73.6 \%)$ & $10(5.8 \%)$ \\
\hline Acute lymphoblastic leukemia & $162(46 \%)$ & $6(3.5 \%)$ \\
\hline Acute myeloblastic leukemia & 97 (27.6\%) & $4(2.3 \%)$ \\
\hline Myelodysplastic syndrome & $23(6.5 \%)$ & - \\
\hline Aplastic anemia & $17(4.9 \%)$ & - \\
\hline Chronic myeloid leukemia & $14(4 \%)$ & - \\
\hline Mucopolysaccharidosis type I & $6(1.7 \%)$ & - \\
\hline Anemia Fanconi & 4 (1.1\%) & - \\
\hline Hodgkin's Lymphoma & $8(2.3 \%)$ & $42(24.4 \%)$ \\
\hline $\begin{array}{l}\text { Immunodeficiency (Wiskott-Aldrich syndrome, Kostmann syndrome, } \\
\text { primary immunodeficiency) }\end{array}$ & 5 (1.4\%) & - \\
\hline Osteopetrosis, leukoencephalopathy Crabbe & $6(1.7 \%)$ & - \\
\hline A malignant tumor (other) & - & 23 (13.4\%) \\
\hline Ewing's Sarcoma & $5(1.4 \%)$ & $50(29 \%)$ \\
\hline Neuroblastoma & $5(1.4 \%)$ & $29(16.9 \%)$ \\
\hline Meduloblastoma & - & 18 (10.5\%) \\
\hline
\end{tabular}


25 patients were in partial remission. Bone marrow (BM) was used as a stem cell source in 244 patients (69\%) allo-HSCT; peripheral blood stem cells (PBSC) were applied in 108 cases (31\%). For auto-HSCT, BM was used in 139 patients (81\%); PBSC were transfused to 33 recipients (19\%). The conditioning regimen for ALLO-HSCT was chosen with respect to the patient's age, primary diagnosis, previous treatment, complications associated with therapy, and somatic status at the time of HSCT. Myeloablative regimens (MR) were used in 148 patient (42\%)s scheduled for allo-HSCT, and in 172 cases $(100 \%)$ intended for auto-HSCT. Non-myeloablative regimens and reduced-intensity doses (NR/RID) were applied to 204 (58\%) patients for allo-HSCT.

Allo-HSCT was performed from related or unrelated donors that were completely or partially compatible for HLA antigens. Related donors were used for 166 patients (47\%) including 51 patients $(31 \%)$ transplanted from HLA-compatible donors, and 115 patients (69\%) with haploidentical stem cells. Matched unrelated donors were used in 186 patients (53\%), including 166 patients (89\%) with HLA-compatible genes $(11 \%)$ and 20 patients with HLA - partially compatible genes (89\%).

The patients with sinusitis as an infectious complication after allo-HSCT were considered a separate clinical subgroup. The group of patients with sinusitis consisted of 78 recipients of allo-HSCT at the age of 2 to 21 years (median of 13 years; the $\mathrm{M} / \mathrm{F}$ ratio was 51:27). Forty-three patients were classified as children $(2-13$ years, median age -9 years $)$, and 35 patients were considered adolescents and young adults ( $14-21$ years, median age -18 years). The primary diagnoses in the group of patients with sinusitis after allo-HSCT are shown in Table 2.

Diagnostic criteria of sinusitis in children and adolescents were based on the common recommendations [19]. The main research methods were as follows: collection of the patients' medical history and complaints to assess overall severity of sinusitis manifestations in the post-transplant patients. A visual analogue scale was graded from 0 (minimal symptomatics) to 10 (maximal severity of symptoms) $[19,20]$. Routine otorhinolaryngological examination was also performed, i.e., anterior and posterior rhinoscopy, pharyngoscopy, otoscopy, indirect laryngoscopy. Endoscopic inspection of nasal cavity was performed using a rigid endoscope with a viewing angle of $0^{\circ}$ (Karl Storz, Germany). Visible changes in mucous membrane of the nasal cavity and nature of secretions the discharge in the nasal passages were evaluated by the endoscopy. The results of this study were recorded on digital media for subsequent analysis. Rigid endoscopes with different angles (Karl Storz, Germany) were also used for endovideoscopy and functional surgery of paranasal sinuses.

The cases of sinusitis were confirmed by X-ray examination, computed tomography (CT) or magnetic resonance imaging (MRI) of the area. PS alterations revealed with CT and MRI techniques were classified by a modified version of Lund method [21]. The degree of PS lesions was scored from 0 to 2. A score of 0 corresponded to absence of the PS disease; 1, partial shading or thickening of the PS mucous membrane; 2 , total shading or fluid levels in PS. Ostiomeatal complexes on the PS images obtained by CT and MRI were evaluated as 0 or 2 points, respectively, free or blocked.

Taking material from the paranasal sinuses for bacteriological and mycological studies was performed by aspiration of the contents of maxillary sinuses during a diagnostic puncture.

Biopsy material was obtained intraoperatively under the control of rigid endoscopes with a viewing angle of $0^{\circ}, 45^{\circ}$, $30^{\circ}$. Prevention of infectious complications was commenced from the first day of conditioning treatment, using the second-generation fluoroquinolones (ciprofloxacin) at a daily dose of $10-15 \mathrm{mg} / \mathrm{kg}$ in 2 injections. To prevent pneumonias, trimethoprim/sulfamethoxazole (Biseptol) was used at a dose of $10 \mathrm{mg} / \mathrm{kg} /$ day (trimethoprim), depending on age, twice a day, 3 times a week. Acyclovir was used at a dose of $200 \mathrm{mg} 3$ times a day as antiviral prophylaxis, starting from the day of hematopoietic restoration.

Primary prophylaxis of fungal infection was performed with drugs from the azole group (triazoles) of different genera-

Table 2. Spectrum of underlying diseases in the group of patients with sinusitis after allo-HSCT ( $n=78)$

\begin{tabular}{|l|l|l|}
\hline Diagnosis & $\begin{array}{l}\text { Children 2-13 years old, } \mathbf{m} / \mathbf{d}=28 / 15 \\
(\mathbf{n}=43)\end{array}$ & $\begin{array}{l}\text { Adolescents, 14-21 years, } \mathbf{m} / \mathbf{d}=23 / 12 \\
(\mathbf{n}=35)\end{array}$ \\
\hline Acute leukemia & $33(76.7 \%)$ & $28(80 \%)$ \\
\hline Acute lymphoblastic leukemia & $24(55.8 \%)$ & $19(54.3 \%)$ \\
\hline Acute myeloblastic leukemia & $9(20.9 \%)$ & $9(25.7 \%)$ \\
\hline Myelodysplastic syndrome & $1(2.3 \%)$ & $2(5.7 \%)$ \\
\hline Aplastic anemia & $2(4.7 \%)$ & $2(5.7 \%)$ \\
\hline Chronic myeloid leukemia & $1(2.3 \%)$ & $1(2.9 \%)$ \\
\hline Mucopolysaccharidosis type I & $1(2.3 \%)$ & - \\
\hline Anemia Fanconi & $5(11.7 \%)$ & - \\
\hline Hodgkin's Lymphoma & - & $2(5.7 \%)$ \\
\hline
\end{tabular}


tions (e.g., Fluconazole), at a dose of 1-2 mg/kg/day. Secondary prevention proceeded with Voriconazole at a dose of 100-200 mg every 12 hours; Posaconazole at a dose of 600-800 mg/day, or a drug from the group of echinocandins (Caspofungin), 50-70 mg/ day, starting on the first day of conditioning and continuing until ceasing the immunosuppressive therapy in the absence of invasive mycoses.

All the patients underwent routine blood and differential leukocyte counts, serum biochemical analysis. Engraftment of donor hematopoietic cells was controlled by the results of clinical blood cell counts, and molecular biology methods (donor chimerism assays). The day of engraftment was defined as achieving neutrophil levels of $>0.5 \times 10^{9} / 1$ without prior stimulation by G-CSF for 3 days, reaching platelet counts of $>25.0 \times 10^{9} / 1$ without prior transfusion of platelet concentrate for 3 days. Severity of thrombocytopenia and neutropenia was assessed in accordance with the World Health Organization classification.

Statistical analysis was performed in Statistica version 10.0 (StatSoft, USA) using nonparametric methods for comparing groups by the quantitative Mann-Whitney criteria, the groups with qualitative characteristics were compared using conjugated tables, t-test, Chi-square and Fisher exact tests. Correlation analysis was performed with Spearman method, log-linear multifactorial analysis. The differences were considered significant by $\mathrm{p}<0.05$.

\section{Results}

\section{Occurrence and severity of sinusitis post-transplant}

The incidence of sinusitis after allo-HSCT was $22.2 \%$ among our patients. It was found that the frequency of sinusitis after allo-HSCT (22.2\%) was significantly higher than after autoHSCT $(1.7 \%, \mathrm{p}<0.001)$. Over recent years, the number of performed allo-HSCT has increased by $33 \%$. Meanwhile, the frequency of sinusitis after allo-HSCT has significantly decreased, i.e., from $39.2 \%$ in 2010 to $10.8 \%$ in 2013 ( $p=0.001$ ), as shown in Fig. 1.

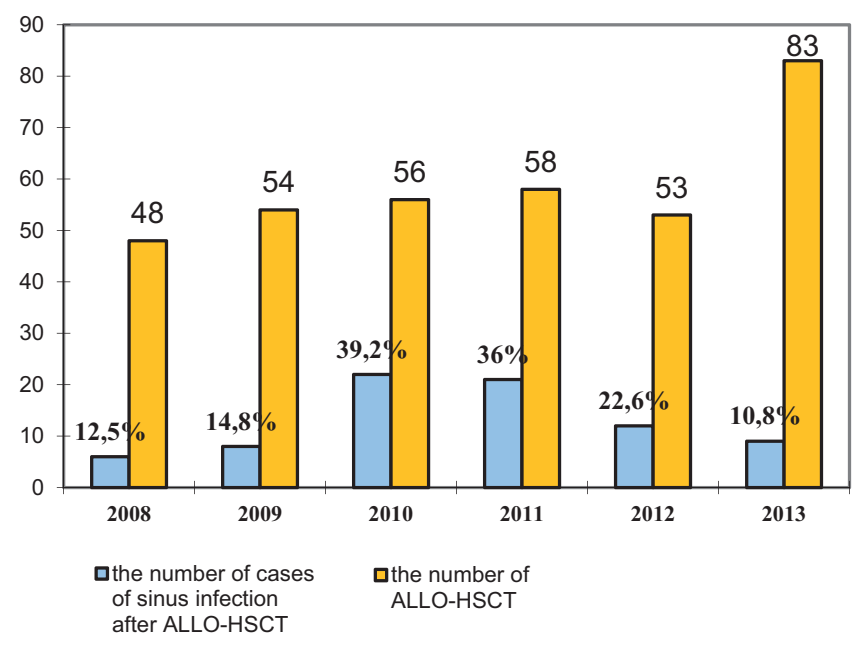

Figure 1. Annual numbers of allo-HSCTs and relative frequencies of sinusitis in the cohorts studied
The largest incidence of sinusitis among children and adolescents was observed in 2010 (respectively, 40.5\% and 36.8\%). In 2013 , the sinusitis occurence is progressively reduced to $14.8 \%(p=0.018)$ in the groups of children, and to $6.8 \%$ among adolescents $(\mathrm{p}=0.026)$.

The frequency of sinusitis proved to be higher at later terms (>100 days after allo-HSCT). Incidence of sinusitis within 100 days post-transplant was $9.6 \%$, as compared to $17.7 \%$ after $\mathrm{D}+100(\mathrm{p}=0.006)$.

Distribution of the PS lesions by their volume in patients after allo-HSCT was as follows: the maxillary sinus (MS) was involved in 24 patients (30.8\%) including unilateral MS affection in 1 case; the MS lesions combined with other PS were detected in 51 cases $(65.4 \%)$, including 13 patients with all the sinuses affected (16.7\%). Isolated lesion of the main sinus was observed in 2 cases $(2.5 \%)$. Inflammation of PS without MS affection was documented in 3 cases (3.8\%).

A decrease in the number of clinical symptoms of sinusitis $(\mathrm{p}=0.008)$, and an increase in cases of mild sinusitis on a visual analog scale $(\mathrm{p}=0.032)$ was registered since 100 days post-transplant (Fig. 2).

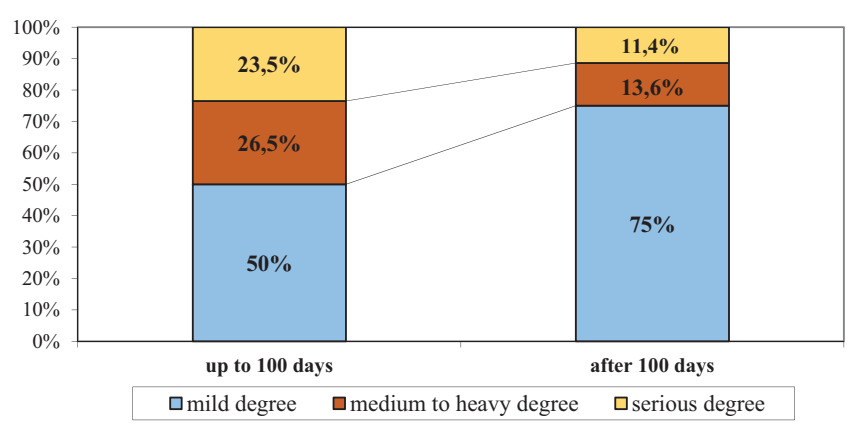

Figure 2. Time-dependent dynamics of clinical sinusitis manifestations according to visual analogue scale period after allo-HSCT

In the patients with neutropenia of I-IV degree at several weeks post-HSCT, severe changes in paranasal sinuses were more often noted by means of CT technique $(\mathrm{p}=0.018)$. However, in $50 \%$ of cases (24/48). In view of clinical severity of PS affection detected by CT, there were changes in severe-grade cases, and such changes in PS were more common after $>100$ days post-transplant ( $\mathrm{p}=0.014)$ (Fig. 3).

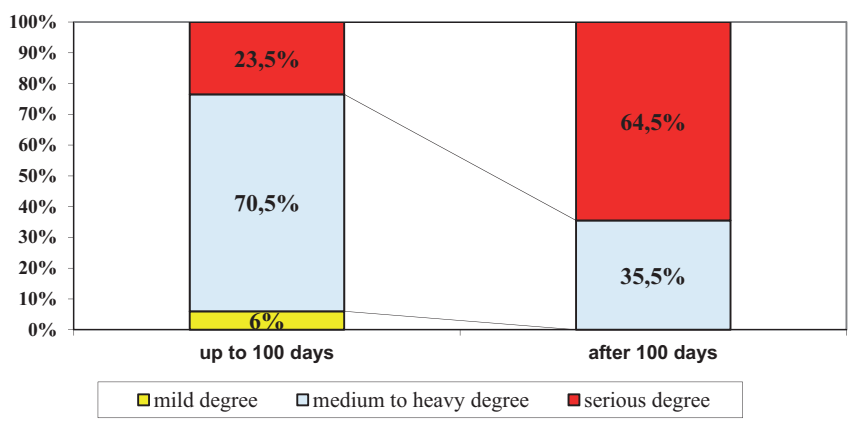

Figure 3. Dynamics of changes in the sinuses detected by computer tomography, depending on the time period after allo-HSCT 


\section{Endoscopy pattern}

Endoscopic images showed non-specific changes in the patients with sinusitis after allo-HSCT. Hyperemia of the nasal mucosa was significantly less common (17\%) than mucosal pallor in the nasal cavities $(83 \%, \mathrm{p}<0.001)$. Oedematous nasal mucosa was observed in $38.5 \%$ of the cases. In $51 \%$ of cases, there was a discharge secretion in the nasal passages, with slimy discharge being a dominating type (80\%). The secretions revealed in the nasal passages in patients with sinusitis after allo-HSCT are classified in Fig. 4.

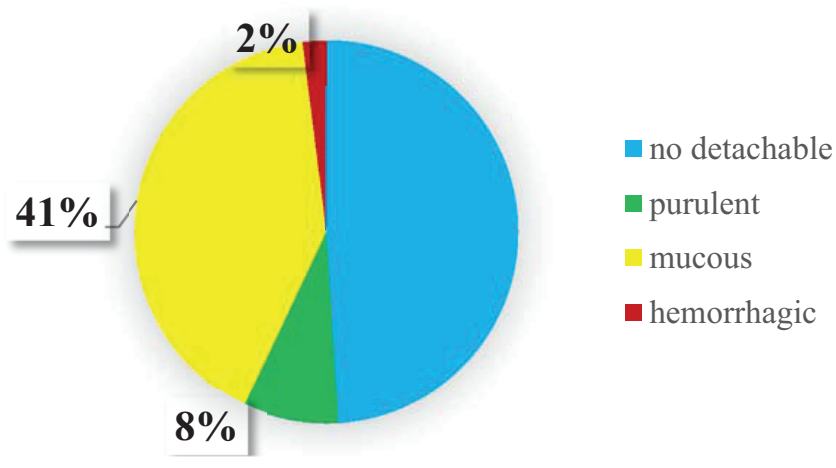

Figure 4. Incidence of secretions revealed in the nasal passages by endoscopy of the nasal cavity in patients with sinusitis post-allo-HSCT

\section{Infectious agents in sinusitis}

In the course of this study, 41 bacteriological and mycological analyses of the samples from maxillary sinuses were performed. The specimens were obtained during diagnostic and therapeutic puncture. Briefly, any pathogen growth was not detected in 10 cases $(24.4 \%)$, bacterial monocultures were isolated in 15 cases (36.6\%); fungal monocultures were obtained from two samples $(4.9 \%)$. The results concerning maxillary sinus aspirate were as follows: inflammation associated with bacteria in $51.2 \%$ of cases $(n=21)$, fungal cultures were obtained in $19.5 \%$ of cases $(n=8)$, and mixed infection was revealed in 2 cases (4.9\%), as shown in Fig. 5.

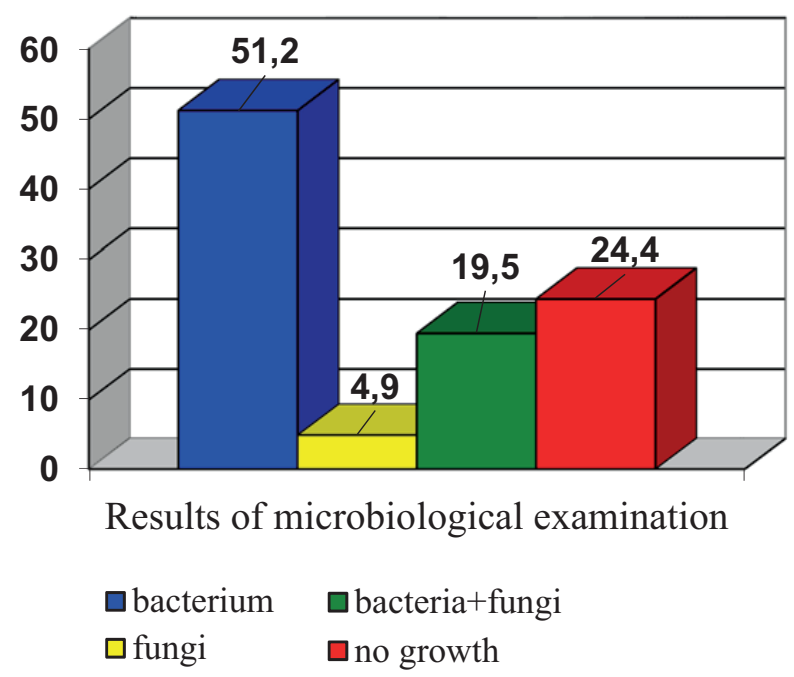

Figure 5. Results of microbiological cultures of maxillary sinus aspirate from the sinusitis patients
The main sinusitis-associated pathogens in allo-HSCT recipients were Gram-positive bacteria: Staphylococcus epidermidis (30\%), Streptococcus viridans (30\%); Gram-negative Klebsiella pneumoniae (17.5\%). The frequency of fungal sinusitis after allo-HSCT was 5\%; association of bacteria and fungi was observed in $20 \%$ of cases. Aspergillus moulds proved to be the main causative agents in fungal sinusitis ( $80 \%$ of positive samples).

After 100 days from allo-HSCT, a larger proportion of sinus secretions showed the absence of microflora growth $(p=0.022)$. It should be noted that the bacterial monocultures predominated up to 100 days from allo-HSCT $(p=0.011)$. Incidence of bacterial sinusitis up to 100 days from allo-HSCT was $74 \%(14 / 19)$; after 100 days from allo-HSCT it was $32 \%$ $(7 / 22)(\mathrm{p}=0.018)$.

A comparative analysis of children and adolescent groups has revealed that combined infections were more often observed in adolescent patients with sinusitis $(\mathrm{p}=0.042)$.

\section{Treatment of sinusitis}

When assessing duration of sinusitis treatment, we have noted that the patients after auto-HSCs recovered faster than the patients after allo-HSCT $(\mathrm{p}=0.007)$. In our study, a recovery from sinusitis occurred within 15 days in $5 \%$ of patients after allo-HSCT, whereas $92.5 \%$ of such patients received therapy for $>30$ days. In $2.5 \%$ of cases, the treatment period was more than 100 days. Terms of treatment and methods of therapy for different age groups are presented in Table 3.

The sinusitis treatment in pediatric patients was longer than in adolescent group $(\mathrm{p}=0.018)$. Usage of MS puncture in combination with antimicrobial therapy significantly reduces the duration of sinusitis treatment $(p=0.024)$, especially in severe changes in the sinuses on CT $(\mathrm{p}=0.035)$.

Diagnostic and treatment punctures were performed in 41 (52.6\%) patients with mandatory sampling of biomaterial for bacteriological and mycological examinations. Age of patients at the time of puncture ranged from 4 years to 21 years. In the children under 7 years, the procedure was carried out under the endotracheal anesthesia in the operating room.

At the time of the puncture, 26/41 (63.4\%) patients had a blood platelet level $<100.0 \times 10^{9} / \mathrm{L}$. Of them, $20 / 26(77 \%) \mathrm{pa}-$ tients did not exceed the level of $50.0 \times 10^{9} / \mathrm{L}(\mathrm{p}=0.0001)$. We have not confirmed a relationship between the frequency of bleeding after the procedure and platelet levels $(\mathrm{p}=0.935)$.

Pneumonia and bronchitis after a sinus infection in recipients of HSCT was observed in $70.5 \%$ of cases (55/78). When analyzing the incidence of lung lesions due to sinusitis in HSCT recipients, depending on the period after allo-HSCT, we have revealed that the pulmonary lesions were observed more often before D+100 after allo-HSCT (28/34, 82\%) than after 100 days $(27 / 44,61 \%, \mathrm{p}=0.049)$.

The endoscopic sinus surgery was performed in 4 patients (5\%) under general anaesthesia, indications for the operation were: orbital complications (reactive edema of the eyelids and local face areas), invasive fungal infection. At the time of surgical treatment, the blood platelet levels in pa- 
Table 3. Duration of treatment of sinusitis in groups and with different methods of therapy

\begin{tabular}{|l|l|l|}
\hline Group & The median terms of treatment, Median & $\mathbf{p}$ \\
\hline Children & 61 day (20-240 days) & 0.010 \\
\hline Adolescents & 40 days (15-92 days) & \\
\hline After allo-HSCT & 39 days (15-240 days) & \multirow{2}{*}{0.016} \\
\hline After auto-HSCT & 15 days (14-30 days) & \\
\hline Systemic antimicrobial therapy & 61 day (20-240 days) & \multirow{2}{*}{0.024} \\
\hline Systemic antimicrobial therapy + puncture treatment & 44 days (15-120 days) & \\
\hline
\end{tabular}

tients ranged from 15.0 to $50.0 \times 10^{9} / \mathrm{L}$, complications after surgery were not observed.

The mono- and multifactorial analysis have revealed several risk factors for sinusitis after allo-HSCT: a story of sinusitis before allo-HSCT $(\mathrm{p}<0.001)$, acute $(\mathrm{p}=0.022)$ or chronic graft-versus-host disease $(\mathrm{p}<0.001)$. In unifactorial analysis, the duration of neutropenia more than 10 days was also associated with sinusitis risk $(\mathrm{p}=0.054)$.

\section{Discussion}

According to different studies, the frequency of sinusitis in adult patients after allo-HSCT ranges from 11 to $51 \%[3,8$, $15,16,18]$. In our group of patients, the frequency of sinusitis after allo-HSCT was $22.2 \%$. Our study has also shown that the sinusitis frequency after allo-HSCT is higher than after auto-HSCT ( $\mathrm{p}<0.001)$, which coincides with results from other groups $[8,11,18]$.

Previous studies have noted that the presence of acute or chronic graft-versus-host reaction (GVHD) comprises a risk factor for sinusitis after allo-HSCT [18]. In our study, we found a correlation between these factors and sinusitis occurrence. Presence of acute $(\mathrm{p}=0.022)$ or chronic GVHD ( $\mathrm{p}<0.001$ ) was associated with significant increase of paranasal sinus pathology after allo-HSCT.

In the patients with immunodeficiency of either origin (neutropenia, HSC recipients, HIV infection) nosocomial infections were more common associated with Gram-negative bacteria (Pseudomonas aeruginosa, Klebsiella pneumoniae, Escherichia coli, Proteus spp., Enterobacter spp., Citrobacter), as well as Gram-positive bacteria such as Staphylococcus aureus (15.3\%), Streptococcus pneumoniae, Enterococcus faecalis $[18,22]$. In our study, the main local causative agents of sinusitis revealed in allo-HSCT recipients were Gram-positive bacteria Staphylococcus epidermidis (30\%), Streptococcus viridans (30\%), or Gram-negative bacteria, e.g., Klebsiella pneumoniae (17.5\%). It was found that the proportion of negative cultures from the sinuses was higher at the terms of $>100$ days after allo-HSCT $(\mathrm{p}=0.022)$. It should be noted that the monocultures of bacteria prevailed up to 100 days from allo-HSCT $(p=0.011)$. The findings for combined sinusitis-associated infections were more often observed in adolescent patients, in comparison with children group $(\mathrm{p}=0.042)$.

In assessing the duration of sinusitis treatment, we have noted that the patients after auto-HSCT recovered faster than patients after allo-HSCT $(\mathrm{p}=0.007)$. This fact may be asso- ciated with a faster recovery of the body's defense mechanisms after auto-HSCT than following allo-HSCT, as well as the lack of immunosuppressive therapy in autologous transplants. In our study, recovery from sinusitis occurred within 15 days in $5 \%$ of patients after allo-HSCT; $92.5 \%$ of patients received therapy for 30 days or more. In $2.5 \%$ of patients, the treatment period exceeded 100 days post-transplant. The use of PPP puncture in combination with antimicrobial therapy significantly reduces the duration of sinusitis treatment $(\mathrm{p}=0.024)$, especially in cases with severe changes in paranasal sinuses registered by $\mathrm{CT}$ and MRI $(\mathrm{p}=0.035)$. In pediatric patients, sinusitis treatment was longer than in the adolescent group $(\mathrm{p}=0.018)$.

\section{Conclusion}

1. Sinusitis folowing allogeneic HSCT occurs more frequently than in auto-transplants;

2. The significant factors for the post-transplant sinusitis are: sufficient immunosuppression, e.g., associated to acute or chronic GVHD;

3. Opportunistic microflora in local samples from the sinusitis patients was found in a half of microbiological cultures.

\section{Conflict of interest}

The authors report no conflicts of interest.

\section{References}

1. Ivanchenko OA, Lopatin AS. Chronic rhinosinusitis: epidemiology, classification, etiology, pathogenesis. Modern view on the problem. Vestn Otorhinolaryngol. 2012; 2: 91-96 (In Russian).

2. Pluzhnikov MS, Lavrenova GV, Katinas EB. Basic principles of immunocorrecting therapy in otorhinolaryngology. Vestn Otorhinolaryngol. 2008. № 4:7-12 (In Russian).

3. Arulrajah S, Symons H, Cahoon EK, Tekes A, Thierry A, Huisman G M, Izbudak I. Relationship between clinical sinusitis symptoms and sinus CT severity in pediatric post bone marrow transplant and immunocompetent patients. Eur J Pediatr. 2012; 171(2): 375-381.

4. Slavsky AN, Pshonkina DM, Svistushkin VM. Bacteriophages in the complex treatment of acute bacterial rhinosinusitis. Rus Med J. 2014; 2:1925-1928 (In Russian). 
5. Bento LR, Ortiz E, Nicola EM, Vigorito AC. Sinonasal disorders in hematopoietic stem cell transplantation. Braz J Otorhinolaryngol. 2014; 80(4): 285-289.

6. Afanasyev BV, Volkova OY, Ganapiev AA. In: Afanasyev, BV (Ed). Hematology: A Guide for Doctors. St.Petersburg: Speclit. 2008. - 238 p (In Russian).

7. Weinberg K, Blazar BR, Wagner JE, Agura E, Hill BJ, Smogorzewska M, Koup RA, Betts MR, Collins RH, Douek DC. Factors affecting thymic function after allogeneic hematopoietic stem cell transplantation. Blood. 2001; 97(5): 1458-1466.

8. Thompson AM, Couch M, Zahurak ML, Johnson C, Vogelsang GB. Risk factors for post-stem cell transplant sinusitis. Bone Marrow Transplant. 2002; 29(3): 257-261.

9. Appelbaum FR. Hematopoietic-cell transplantation at 50. New Engl J Med. 2007; 357(15):1472-1475.

10. Gratwohl A, Baldomero H, Aljurf M, Pasquini MC. Hematopoietic stem cell transplantation. A global perspective. J Am Med Ass. 2010;303(16):1617-1624.

11. Won YW, Yi SY, Jang JH, Kim K, Kim SJ, Kim WS, Jung $\mathrm{CW}$, Kim DH. Retrospective analysis of paranasal sinusitis in patients receiving hematopoietic stem cell transplantation. Int J Hematol. 2011; 93(3):383-388.

12. Inaba H, Hartford CM, Pei D, Posner MJ, Yang J, Hayden RT, Srinivasan A, Triplett BM, McCulllers JA, Pui $\mathrm{CH}$, Leung W. Longitudinal analysis of antibody response to immunization in paediatric survivors after allogeneic haematopoietic stem cell transplantation. Br J Haematol. 2012; 156(1): 109-117.

13. Meng L, Huang XJ. Allogeneic hematopoietic stem cell transplantation in China: where we are and where to go. J Hematol Oncol. 2012. 5(1):10.

14. Mortellaro C, Mortellaro C, Barat V, Nesi F, L. Bello, G. Bologna, D. Farronato, A. G. Lucchina, A. Linari. Intercurrent infectious diseases in post-stem cell transplant patients: paranasal sinusitis. J Craniofac Surg. 2012; 23(1):153-157.

15. Meyers JD. Infection in bone marrow transplant recipients Am J Med. 1986; 81(1):27-38.

16. Shibuya TY, Momin F, Abella E, Jacobs JR, Karanes C, Ratanatharathorn V, Sensenbrenner LL, Lum LG. Sinus disease in the bone marrow transplant population: incidence, risk factors, and complications. Otolaryngol Head Neck Surg. 1995; 113(6):705-711.

17. Deutsch JH, Hudgins PA, Siegel JL, Peterman SB, Devine SM, York R, Wingard JR. The paranasal sinuses of patients with acute graft-versus-host disease. Am J Neuroradiol. 1995; 16(6):1287-1291.

18. Savage DG, Taylor P, Blackwel J, Chen F, Szydlo RM, Rule SAJ, Spencer A, Apperley JF, Goldman JM. Paranasal sinusitis following allogeneic bone marrow transplant. Bone Marrow Transplant. 1997; 19(1):55-59.
19. Fokkens WJ, Lund VJ, Mullol J, Bachert C, Alobid I, Baroody F, Cohen N, Cervin A, Douglas R, Gevaert P, Georgalas C, Goossens H, Harvey R, Hellings P, Hopkins C, Jones N, Joos G, et al. European Position Paper on Rhinosinusitis and Nasal Polyps Group: European position paper on rhinosinusitis and nasal polyps 2012. Rhinology. 2012; 50 (Suppl 23): 1-329.

20. Lim M, Lew Gor S, Darby Y. The relationship between subjective assessment instruments in chronic rhinosinusitis. Rhinology. 2007; 45(2):144-147.

21. Lund VJ, Kennedy DW. Staging for chronic rhinosinusitis. Otolaryngol Head Neck Surg. 1997: 117(1):35-40.

22. Imamura R, Voegels R, Sperandio F. Microbiology of sinusitis in patients undergoing bone marrow transplantation. Otolaryngol Head Neck Surg. 1999; 120(2): 279-282. 


\title{
Особенности течения, диагностики и лечения синуситов у детей и подростков после трансплантации гемопоэтических стволовых клеток
}

\author{
Екатерина С. Утимишева ${ }^{1}$, Олег И. Долгов ${ }^{1}$, Олеся В. Паина ${ }^{1}$, Кирилл А. Екушов ${ }^{1}$, Алина А. Витрищак ${ }^{1}$, \\ Борис И. Смирнов ${ }^{2}$, Людмила С. Зубаровская ${ }^{1}$, Сергей А. Карпищенко ${ }^{1}$, Борис В.Афанасьев ${ }^{1}$ \\ ${ }^{1}$ Первый Санкт-Петербургский государственный медицинский университет им. академика И. П. Павлова, Россия \\ ${ }^{2}$ Санкт-Петербургский государственный электротехнический университет «ЛЭТИ», Россия
}

\section{Резюме}

Синусит после аллогенной трансплантации гемопоэтических стволовых клеток возникает в 22,2\% случаев с более высокой частотой после 100 дня от алло-ТГСК, чем до 100 ( $\mathrm{p}=0,006)$. Основными факторами риска возникновения синусита после аллогенной трансплантации гемопоэтических стволовых клеток являлись: синусит до алло-ТГСК ( $<<0,001)$, длительность нейтропении более 10 дней $(\mathrm{p}=0,054)$, наличие у пациентов острой $(\mathrm{p}=0,022)$ или хронической «реакции трансплантат против хозяина» ( $\mathrm{p}<0,001)$. Основными возбудителями острых синуситов у реципиентов алло-ТГСК в исследовании являлись грамположительные бактерии Staphylococcus epidermidis (30\%), Streptococcus viridans (30\%), грамотрицательные бактерии Klebsiella pneumoniae $(17,5 \%)$. Монокультура бактерий преобладала до 100 дня от алло-ТГСК ( $\mathrm{p}=0,011)$. У пациентов подросткового возраста чаще наблюдался полиэтиологичный характер возбудителей синусита по сравнению с группой «дети». Степень тяжести изменений околоносовых пазух на компьютерной томографии после 100 дня от алло-ТГСК более выражена $(\mathrm{p}=0,014)$, что находится в дисбалансе с меньшим количеством клинических симптомов синусита $(\mathrm{p}=0,008)$ и более частым течением синусита в легкой степени при оценке по визуальной аналоговой шкале $(\mathrm{p}=0,032)$ в этот период. Применение пункций верхнечелюстных пазух в сочетании с противомикробной терапией сокращает сроки лечения синусита у этих пациентов ( $\mathrm{p}=0,024)$.

\section{Ключевые слова}

Синусит, дети, трансплантация гемопоэтических клеток, клинические особенности. 